実 験 技 術

抗体による c DNA ライブラリーの模索 $: \lambda \mathrm{gt} 11$ の例

$\begin{array}{llr}\text { 基礎生物学研究所 } & \text { 浜田 } & \text { 義雄 } \\ \text { 生 理 学 研究 所 } & \text { 三川 } \\ \text { 筑 波 大 学 } & \text { 真崎 } & \text { 知生 }\end{array}$

はじめに

遺伝子操作技術の発展とともに梯々な遺伝子クロー ニングの方法が開発されてきた. 一般的かつ古典的な 方法では特定の mRNA を庶糖密度勾配遠心等で濃縮 精製し，ほほ単一のmRNA標品にする.この mRNA に対してcDNA を合成しその後の遣伝子解析に供す る方法が広く使われてきた。特定の mRNAの濃縮
精製過程，あるいはcDNAクローニングのcDNAの 同定において目的のタンパクに対する $\mathrm{mRNA}, \mathrm{cDNA}$ であるかどうかは in vitro翻訳系で翻訳されたタンハ クの分子量およびその抗原性を抗体で検定することに なる. 抗体での検定段階を in vitro 翻訳系に置くよ りもcDNAを大腸菌内でタンパクに対する抗体で大腸 菌のコロニーもしくはファージプラークをスクリーニン グする方がより直接的な方法である。外来性の c DNA を大腸菌内でタンパクに翻訳する目的で作られたべク ターをいわゆる experssion ベクターというここの稿で は Young とDavisによって開発されたファージベク タースgt11を使用して抗体で cDNAライブラリーをス クリーニングする方法を紹介する゙',2).

$$
\lambda \mathrm{gt11} \text { の跷造およびスクリーニングの原理 }{ }^{1,2,3)}
$$

$\lambda \mathrm{gt} 11$ のゲノム中には大腸菌の $\beta$ ーガラクトシタ 一ゼ遣伝子 ( lacZ)がある. 外来性のcDNA 在 $\beta$ ーガ ラクトシターゼ遣伝子中の $\mathrm{E}$ co RI 部位に㧴入するこ とになる。cDNAは $1 \mathrm{acZ}$ の転写翻訳のシグナルで $\beta$

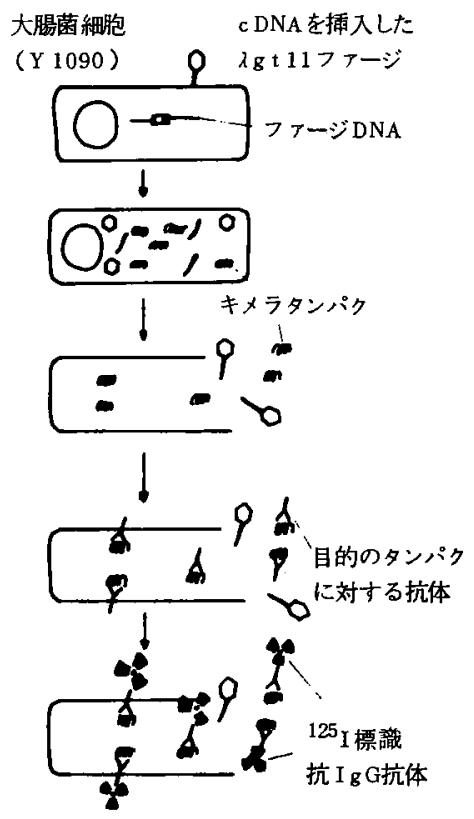

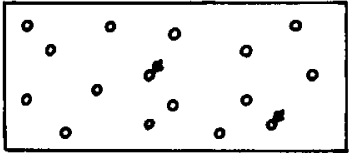

プレート上の

プラークの位置

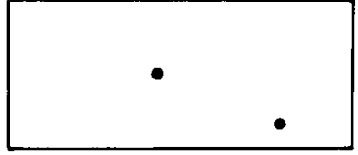

フィルターの

オートラジオグラフ

図 1〈g t11に择入されたcDNAに由来するキメラタンパクの検定の模式図. 
ーガラクトシターゼとのキメラタンパク (fusion protein）の形で発現される. 抗体を使ってのcDNAライ ブラリーのスクリーニングの原理を簡単に模式図の形 で図1に示しておいた。cDNAを持っファージを大腸 菌 Y 1090 に感染させ, IPTC ( isopropyl-D-thiogalactopyranoside, $\beta$ ーガラクトシターゼを誘導する化 学物質) で大腸菌を処理しキメラタンパクをファージ 粒子とともに菌体外に放出させる。キメラタンパクを ニトロセルロースに移しその上で抗原抗体反応を行わ せる. ${ }^{125} \mathrm{I}$ で標識された二次抗体と反応するプラー クが目的とするタンパクのcDNAを持つファージであ る.

\section{CDNA ライブラリーの作製}

最近, in vitro パッケージング用の抽出液, cDNA 合成キット， $\lambda_{\mathrm{gt}} 11$ のアームも市販されているので, cDNAライブラリーの作製は䉍単になっている． c D NAライブラリーさえ市販されるようになった。 ここ
では標準的な c DNAライブラリーの作製方法を述べる. cDNAライブラリーの作製に当たって必要とする c D NA ライブラリーの大きさの見当を付けなければなら ない．目的とする $\mathrm{mRNA}$ の量が全 $\mathrm{mRNA} 0.1 \%$ であるならば, lac ZのE co Rl 部位に㨂入された c DNA がもとのタンパクと同じアミノ酸配列を持っペ プチドになる確率はフレーム及び挿入される cDNAの 方向性から 1/6になるので c DNAライブラリーは最小 $6 \times 10^{3} \mathrm{pfu}$ (plaque forming unit) である.スク リーニングに使用する抗体の抗原認識部位等を考虑に 入れるとさらに10倍の大きさのライブラリーが必要で あろう. cDNAライブラリー作製の手順を図 2 に示し ておいた. 各手順の反応条件を順を追って説明する.

尚，とくに記さない限り緩衝腋及び種々の溶液の組成 は “Molecular Cloning” 4)あるいは醳素の発売元 より指示されている組成に従う.
a. גgt11のアームの調製
1. $\lambda \mathrm{gt} 11$ の DNA $\lambda \mathrm{gt} 11$ の溶原菌 BNN 97 から精

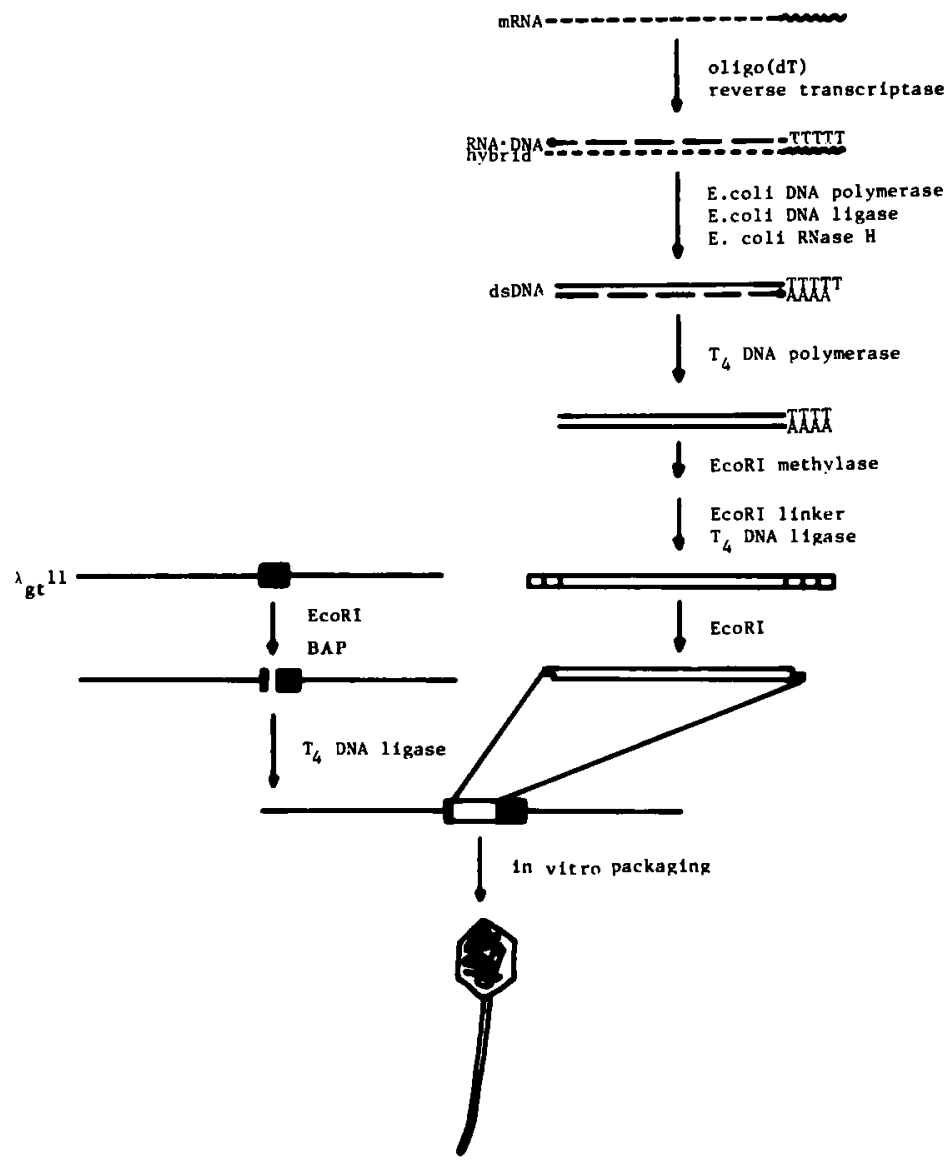

図2〈gt11をべクターとしての c DNAライブラリーの作製方法 
製するが3，もしくは2 gt11ファージをY Y 1088に 感染させ通常の方法で精製する ${ }^{4)}$.

2. $1 \mu \mathrm{g} / \mu \mathrm{|}$ のファージ DNA $40 \mu \mathrm{l}$ に対して $10 \mu \mathrm{l}$ の $5 \times \mathrm{E}$ coRI楥衝液を加える.ささらに $5 \mu 1$ の Eco RI（12 units $/ \mu 1$, 宝酒造)を加えてよく混合した 後 $37^{\circ} \mathrm{C} 1$ 時間消化する.

3. フェノール, エーテル抽出, エタノール沈澱乾燥 後 $45 \mu 1$ の水にとか子.

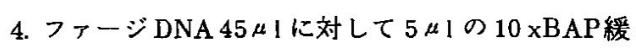

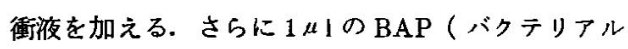
アルカリフォスファターゼ, 250 units $/ 0.56 \mathrm{ml}$.

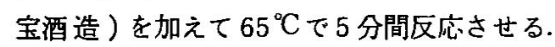

5. フェノール, エーテル抽出, エタノール沈揤乾燥 後 $40 \mu 1$ の水にとかしー $20^{\circ} \mathrm{C}$ で保存する.

注：ファージDNAがEcoRI によって完全に分解されてい るかどうかはステップ2の後，適当な制限醉素 (Hind II あるいは K $\mathrm{pnI}$ ）で切断しアガロースゲルの電気泳動に よって ג gt 11 制限醉素地図より期待されるDNA断片が 得られることを確かめる. 完全分解されていないようた とステップ1を繰り返す. BAP処理はcDNAライブラ リーのパックグランド（cDNAを持たないフォージ）を下 げるために行う. BAP处理後は次の 2 点を点険する必要 がある. 1. スgt11のアーム同士はT4リガーゼによ って再結合されない，2. アームは他の E coRI断片と は結合する.この2 点を満足しない場合は BAP 処理を 繰り返すか䣼素標品を疑う必要がある.

\section{b. 一次 CDNA の合成 ${ }^{4)}$}

1. $1 \mu \mathrm{g} / \mu$ Iになるように水にとかした poly $(\mathrm{A})^{+} \mathrm{R}$ NA $10 \mu 1 に 100 \mathrm{mM} \mathrm{CH}_{3} \mathrm{HgOH} 1 \mu \mathrm{l}$ を加えて $65^{\circ} \mathrm{C}$ で 3 分間インキュベートする。 その後 10 分間室温 に放置する.

2. $700 \mathrm{mM}$ のルルカプトエタノールを $2 \mu 1$ 加え5 分 問室温に放膡する.

3. 以下の順に試薬を加える. $\mathrm{H}_{2} \mathrm{O}^{5} \mu 1,1 \mathrm{mg} / \mathrm{ml}$ の ligo (dT) $5 \mu 1,1 \mathrm{M}$ Tris $-\mathrm{HCl}(\mathrm{pH} 8,3) 5 \mu 1$, $1 \mathrm{M} \mathrm{KCl} 7 \mu 1,250 \mathrm{mM} \mathrm{MgCl}_{2} 2 \mu 1,10 \mathrm{mM} \mathrm{dN}$ TPs (dATP, dGTP, dCTP, dTTP) $5 \mu 1$, 逆転写醭素 $3 \mu 1$ ( 20 units $/ \mu 1$, Life Science) を 加えよくVortexする.

4. $42^{\circ} \mathrm{C}$ で 2 時間反応させる. その後, フェノール 抽出しエタノール沈沅を 2 回綠り返す.

5. 乾燥後 $20 \mu 1$ の水に溶かす ( mRNA-DNA). 逆転写醉素の標品検查を兼机てcDNAが作られてい るかの検定のために反応液の中に $10 \mu \mathrm{Ci}$ の $\alpha-{ }^{32} \mathrm{P}$ $\mathrm{dCTP}(\sim 3000 \mathrm{Ci} / \mathrm{mmol}, \mathrm{NEN})$ を加えておく. こ の反忘条件では全体として $2 \sim 5 \times 10^{5} \mathrm{cpm} の{ }^{32} \mathrm{P} か$
取り込まれる. 合成されたcDNAの平均サイズは 1.5 \%の変性アガロースゲル電気泳動で確かめる. 水酸化 メチル水銀は市販されていないので, 代わりに actinomycin D 使用してもよい ${ }^{5)}$.

\section{c. 二次 cDNA の合成 ${ }^{6)}$}

1. 試薬を次の順で加える. $10 \mathrm{x}$ 緩衙液 $10 \mu 1,1 \mathrm{M}$ $\mathrm{KCl}, 10 \mathrm{mM} \beta-\mathrm{NAD} 0.5 \mu 1,10 \mathrm{mM}$ dNTPs $0.5 \mu 1, \mathrm{H}_{2} \mathrm{O} 76 \mu 1, \mathrm{RNaseH}(1.3$ units $/ \mu 1, \mathrm{P}$. L) $1 \mu_{1}$, E.coli リガーゼ ( 250 units $/ \mu 1$, P. L ) $1 \mu 1$, E. coli DNAポリメラーゼ ( 9 units $\left./ \mu_{1}\right)$ $1 \mu 1$, 上記の mRNA-DNA $1 \mu 1$.

2. $15^{\circ} \mathrm{C}$ で一時間反応する. さらに室温で一時間反 応する.

3. フェノール抽出後上清に, キャリアーとして 10 $\mu \mathrm{g} の$ E. coli t RNAを加え，エタノール沈澱を行 う.もう一度エタノール沈測を繰り返し乾燥させる. 二次 $\mathrm{cDNA}$ 合成する際 $10 \mu \mathrm{Ci}$ の $\alpha{ }^{32} \mathrm{PdCTP}$ を加えて反応の進み具合いを検定しておく方がよい. $5 \times 10^{4} \mathrm{cpm}$ 前後の ${ }^{32} \mathrm{P}$ の取り込みがある. この場 合一次 cDNAの合成時に $\alpha-{ }^{32} \mathrm{PdCTP}$ を加えないで おく必要がある.実験例を図 3 に示しておく。

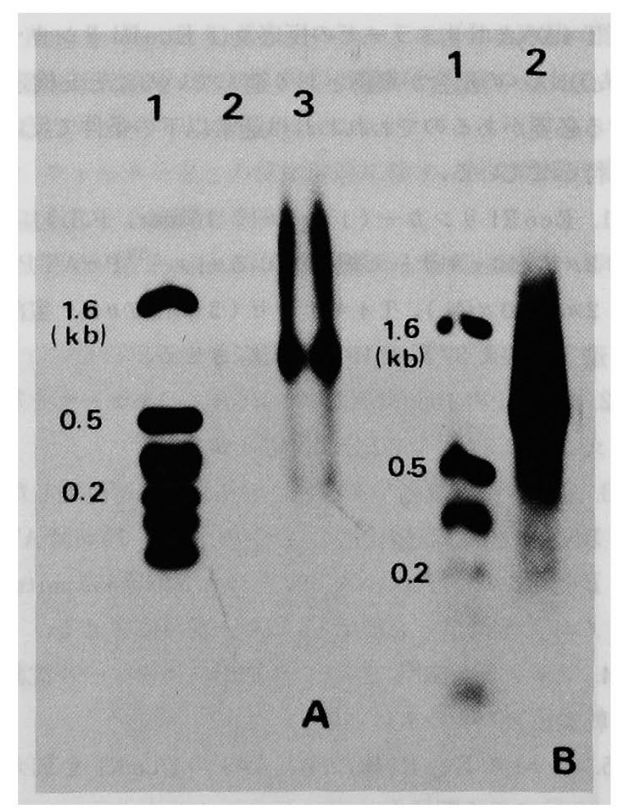

図 3 二次 $\mathrm{cDNA}$ 合成の検定.二本鎖 DNA( ハネルA ) と 一本夓 DNA（パネルB）にした場合のcDNAの長 さを $1.5 \%$ アガロースゲル電気泳動で検定した. cDNAの平均サイズが 300 b p以上あればよい。 レーン 1 : 分子量マーカー. 
d. cDNAのEcoRI 部位のメチレーション

1. 上記乾燥 DNAに水を $21 \mu 1$ 加え DNAをとかす.

2. 以下の順に試楽を加える.1 MT ris $-\mathrm{HCl}(\mathrm{pH} 8$. 0) $5 \mu \mathrm{l}, \mathrm{S}$ アテデノシルメチオニン $(1.86 \mathrm{mM})$ $4 \mu \mathrm{l}, \mathrm{EcoRl}$ メチラーゼ $10 \mu \mathrm{l}$ (40 units/ $\mu 1$. New Englnd Biolabs )を加え $37^{\circ} \mathrm{C}$ で 3 時間反応 させる.

3.フェノール抽出後,エタノール沈沷を 2 回繰り返 し乾燥させる. Sーアデノシルメチオニンは実験直 前に作った方がよい，また反応条件，特に EcoRl メチラーゼは pBR322 を使用して活性及び必要な ユニット数を予め知っておく方がよい。

e. T 4 ポリメラーゼ反応

1. 乾燥した DNAを $6 \mu 1$ の水にとかす.

2. 以下の順に試薬を加える. $5 x$ 楥衝液 $2 \mu 1,10$ $\mathrm{mMdNTPs} 1 \mu 1, \mathrm{~T} 4 \mathrm{DNA}$ ポリメラーゼ$(1.6$ units $/ \mu 1$, 宝酒造 )，1 $1 \mu$ ] .

3. $37^{\circ} \mathrm{C}$ で 15 分間反応させた後,フェノール抽出を する.

4. エタノール沈殹を 2 回おこない乾燥させ, $1 \mu 1 の$ 水にとかす.

f. cDNAのEcoR! 部位の作製

T 4 DNAポリメラーゼの反応及び E coR1リンカー の cDNAへの結合が期待どおり進んでいることを検定 する必要があるのでわれわれは通常以下の条件で反応 を行わせている。

1. EcoR! リンカー $(1 \mu \mathrm{g} / \mu \mathrm{l}, 10 \mathrm{mer}, \mathrm{P} . \mathrm{L})$ $2 \mu 1,10 \mathrm{x}$ キナーゼ緩衝液 $0.5 \mu 1 r-{ }^{32} \mathrm{P}$-A T P $2 \mu 1(20 \mu \mathrm{Ci}), \mathrm{T} 4$ キナーゼ ( 5 units $/ \mu 1$, 宝酒 造）を加え $37^{\circ} \mathrm{C}$ で 15 分間反応させる.

2. $0.5 \mu 1$ の $10 \mathrm{mM} \mathrm{ATPと} 0.5 \mu 1$ のキナーゼを加 えさらに $37^{\circ} \mathrm{C} て ゙ 30$ 分間反応させる.

3. 全量の反応液を T 4 DNA ポリメラーゼ処理した DNAに移し 2 x緩衝液を $1 \mu$ 加える. $10 \mathrm{mM} \mathrm{AT}$ Pを $0.5 \mu \mathrm{l}$ ， T 4 DNAリガーゼ $0.5 \mu$ I ( 350 units $\mid \mu 1$ ，宝酒造）を加え $12^{\circ} \mathrm{C}$ で一晚反応させる.

4.フェノール抽出, エーテル抽出, ‘タノール沈䬦, 乾燥後 $40 \mu 1$ の水にとかす.

5. $10 \mu \mid \sigma \mathrm{EcoR} 1$ 緩衝夜と $5 \mu \mid$ E $\operatorname{coR} 1$ を加え $37^{\circ} \mathrm{C}$ で 3 時間消化する.

6. 4，5の操作を繰り返す.

7. EcoRI 反応液を $10 \mathrm{mM}$ Tris $-\mathrm{HCl}(\mathrm{pH} 8.0) /$ $10 \mathrm{mM} \mathrm{NaCl} / 1 \mathrm{mM} \mathrm{EDTA} / 0.1 \% \mathrm{SDS}$ C゙平衡化 した Sephadex G-200のカラムにのせる. BioGelA-50m) でもよい.

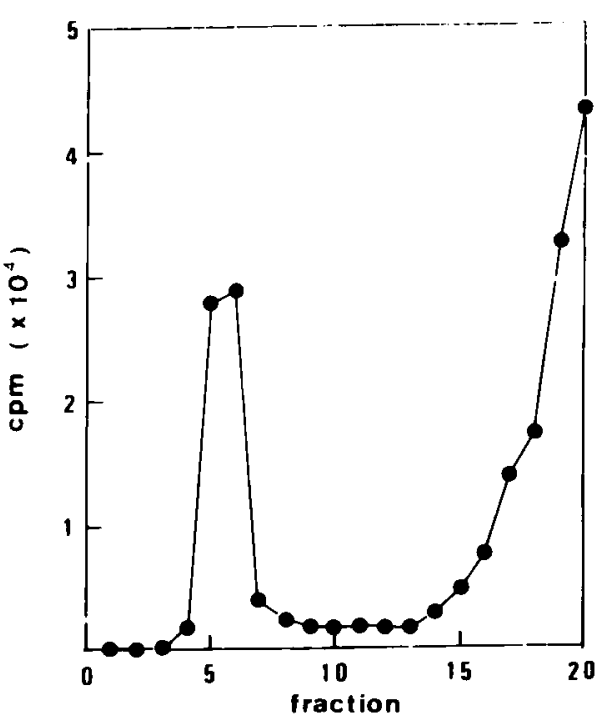

图 4 cDNAの Sephadex G-200からの溶出パターンの

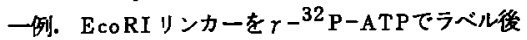
cDNA と結合させた。 その後EcoRI処理し cDNA と遊雅の EcoRI を分雄した。 カラムは $0.7 \mathrm{~cm}$ (直径) $\times 30 \mathrm{~cm}$ (長さ)である.

8. 10 滴ずつエッペンドルフのチューブに分画しシン チレーションカウンターで測定する（図 4 ）。

9. 最初のピークを集めフェノール抽出，エーテル抽 出，エタノール沈溊乾燥させる.リンカーのみがラ ベルされた場合 $2 \times 10^{4} \mathrm{cpm}$ 前後のカウントが得ら れる.

10. DNAを $5 \mu 1$ の $\mathrm{H}_{2} \mathrm{O}$ にとかしてー $20^{\circ} \mathrm{C} に$ 保存す る.

g. cDNA と $\lambda \mathrm{gt} 11$ との桔合

1. 上記の cDNA $1 \mu$ と $\lambda \mathrm{gt} 11$ アーム $(0.5 \mu \mathrm{g} / \mu \mathrm{l})$

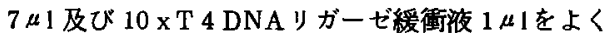

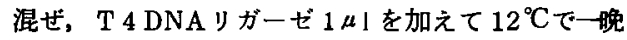
反応させる.

2. in vitro パッケージングをおこなう.

cDNAと入gt11のアームとのモル比は $1 ： 2$ にな るようにする. in vitro パッケージング用抽出液の作 製方法及びパッケージングの方法は紙面の都合上他の 文献を参照されたい $4,7,8$ ），パッケージング後の溶液 の一部を取り，cDNAライブラリーの大きさを測定す る. $\lambda \mathrm{gt} 11$ の宿主としてはY 1068 を使用する. Xgal ( 5-bromo-4-chloro-3-indol- $\beta-\mathrm{D}-$ galactoside) の入ったアガープレートでプラークを作らせる.

cDNAを持っているファージは無色のプラークを作り, 持っていないフォージは青色のプラークを作る. 無色 


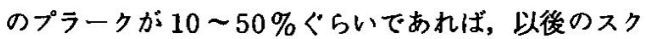
リーニングに使用できると考えられる.

h. cDNAライブラリーの増幅 ${ }^{3)}$ cDNAライブラリーはいったん増幅 ( amplification）させた後スクリーニングに使用する.

1. $0.2 \mathrm{ml}$ のY 1088 の培美 $\left(O D_{600 \mathrm{~nm}}=1.0\right)$ を試 験管に入れる.

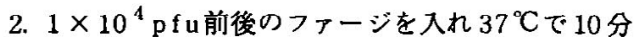
間インキュベートする.

3. $6 \mathrm{ml}$ の軟寒天を加える. 寒天は $0.7 \%$ になよ

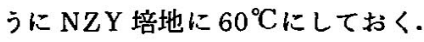

4. 軽くVortex したあと $50 \mathrm{ml}$ のボトムアガーの入

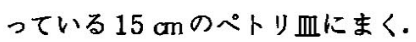

5. $4 \sim 6$ 時間インキュベートする. これくらいの時 間でプラークがはうきり見えるようになる. 長くイ ンキュベートしないようにする.

6. 軟寒天を集め SMに彩濁し，よくかき混ぜた後, 一晚 $4{ }^{\circ} \mathrm{C}$ に放置し $6,000 \mathrm{rpm} 10$ 分間の遠心で上清 を集める.上清は分注した後 $4{ }^{\circ} \mathrm{C} て ゙$ 保存する.

i . 抗体によるcDNA ライブラリーの検索 ${ }^{3}$ )

ポリクローナル抗体の場合は問題とならないがモ， クローナル抗体ではハプテン部位を含まないcDNAを 逃がしてしまう可能性がある.できれば異なるハプテ ンを認識するモノクローナル抗体を数種類混ぜポリク ローナル抗体のように用いることを萀める. 用いる抗 体の必要条件がある. 最む重要な条件は $100 \mathrm{pg} / \mathrm{mm}^{2}$ 以下の抗原を検出できる抗体でなければならない.

これは野生型 $\lambda \mathrm{gt} 11$ プラーク 1 個当たり合成される ßーガラクトシターゼが $100 \mathrm{pg} \sim 1 \mathrm{ng}$ 程度であると 推定されているためである (渡辺, 私信 ). 奏際これ より感度の弱い抗体でのスクリーニングはすべて失敗 している.

1. Y 1090 の単一コロニーを LB培地中で $O D_{600 \mathrm{~nm}}$ $=1.0$ まで培養する.

2. $0.2 \mathrm{ml}$ の培とうに $0.1 \mathrm{ml}$ のファージ希釈液を加 えて $37^{\circ} \mathrm{C}, 15$ 分閒ファージを感染させる. ファー ジ数は $0.1 \mathrm{ml}$ 中に $1 \times 10^{4} \mathrm{pfuになるようにして}$ おく.

3. $60^{\circ} \mathrm{C}$ に保温しておいた $0.7 \%$ LBアガロース $6 \mathrm{ml}$ を加えかるくVortex したあと前もって作っておい たアガーゲルの上にまく. $1.2 \%$ ○アガーは $37^{\circ} \mathrm{C}$ で 30 分間ぐらいその表面を乾焻させた後, 軟寒天 をまく直前まで $37^{\circ} \mathrm{C} に$ 保温しておく・プレートは ニッスイより市販されている長方形 $(7.5 \mathrm{~cm} \times 22.5$ $\mathrm{cm}$ )のものを薦める.
4. $42{ }^{\circ} \mathrm{C} て ゙ ~ 3 \sim 4$ 時間インキュベートする.

5. $10 \mathrm{mMI}$ PTGに前むってひたし, 水切りした二 トロセルロースフィルターを各プレートの上におく.

6. 一晚 $37^{\circ} \mathrm{C}$ でインキュベート寸る.

7. ニトロセルロースのプレート上の位直の同定が簡 単に出来るように適当な印をフィルターとプレート に付ける.

8.フィルターを静かにプレートからはがしたあと $0.1 \%$ Triton X-100 を含むPBS ( pH 7.0) で洗 浄する.フィルターの洗浄，抗体反応は震とう条件 下でおこなう $(75 \mathrm{rpm})$. 洗浄液の交換をしながら フィルターより培地の色がなくなるまで行う.

9. $0.1 \%$ Triton $X-100$ 及び $10 \sim 20 \%$ の馬血清を 含むPBS中で 15 分前後フィルターをインキュベー トする.

10. 抗体を $100 \mathrm{pg} / \mathrm{mm}^{2}$ 程度の抗原が検出できる範囲 に $10 \%$ 馬血清を含むPBSで希积する.ここでウサ ギのポリクローナル抗体あるいは血清でスクリーニ ングする場合は，大腸菌に対する抗体などが混入し ているのでこれを除く必要がある，それには希釈抗 体溶液 $1 \mathrm{ml}$ にたいし，ファージ溶菌液を一滴加え 5 分閒待てばよい：ここでファーシ溶菌液とは，Y 1090 を $\lambda \mathrm{gt} 11$ (ベクターのみ) で通常の方法で溶 菌させ大腸菌の残さを遠心で除いた上清のことであ る.

11.フィルターをこの抗体溶液に移す. 反応時閒は室 温で 1 - 2 時間である.

12. $0.05 \%$ Tween 20 あるいは $0.1 \%$ Triton $X-100$

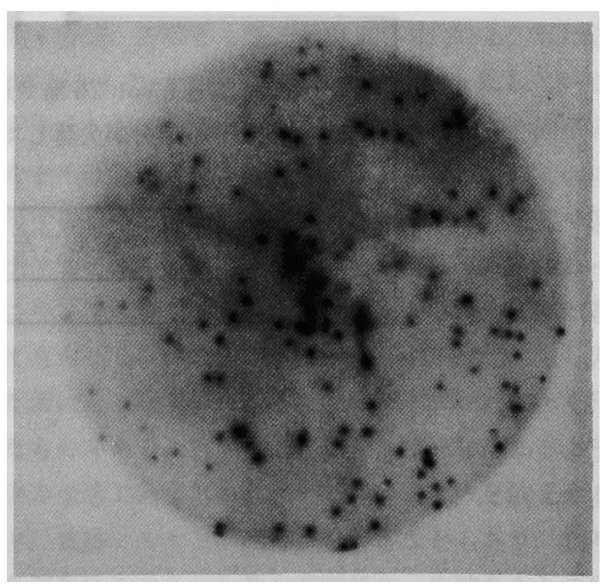

図 5 ニワトリ砂整ミオシン重鎖 cDNAの二次スクリー ニング. 半数のプラークが抗ミオシン抗体と反応 している. 露光時間は 1 日. 
を含む PBS で室温 15 分間 3 回以上洗浄する.

13. ${ }^{125} \mathrm{I}$ 標識抗ウサギ $\mathrm{IgG}$ g抗体（Amersham) を 通常 100 倍程度に $20 \%$ 馬血清を含むPBS で希釈 して用いる. 希釈液にファージ溶菌液を 10 と同様加 えて 5 分後フィルターとの反応を開始する. 室温で 30 分間から 2 時間行なう。反応時間は一次抗体の 特性によって異なる。

14. 12 の操作を繰り返し,フィルターを乾燥させ増 感スクリーンを用いてー70 $\mathrm{C} て ゙ X$ 楾フィルムに露 光させる.

実験例としてニワトリ砂重のミオシン重鎖のクロー ニングを図 5 に示す.

\section{おわりに}

expression ベタターとしてはプラスミドが先に作 られている.その原理は基本的にここで紹介した t11 と同じである.どちらかのべクターを使用するか は実験目的に応じて選ぶことになる.目的の mRNA に対するモル比が，小さい場合は大きなcDNAライブ ラリーが必要であり，作りやすいという点からファー ジベクターの方を萀める. しかしながらファージベク ターを使用する場合，合成されるキメラタンパク量が プラスミドをべクターとした場合の合成量に比べて少 ないという欠点を持つ.スクリーニングに使用する抗 体の感度が悪いとクローニングできないことになる.
良い抗体を作ることが先決であるが抗体の善し覀しは 人知の及ばないところもあるので，抗原の合成量を増 加させるか検出感度を高める必要がある. 検出感度を 高める方法としては抗 $\beta$ ーガラクトシターゼ抗体を使 用することが考えられている（渡辺，私信）。

\section{文献}

1) Young, R. A. and Davis, R. W. (1983) Proc. Natl. Acad. Sci. USA, 80, 1194.

2) Young, R. A. and Davis, R. W. (1983) Science, 222, 778.

3) Huynh, T. V., Young, R. A. and Davis, R. W. (1985) in DNA Cloning: A Practical Approach, Glover, D. M. (ed), IRL Press, Oxford, pp. 49.

4) Maniatis, T., Fritsch, E. F. and Sambrook, J. (1982) Molecular Cloning, Cold Spring Harbor Laboratory, Cold Spring Harbor, New York.

5) Reinach, F. C. and Fischman, D. A. (1985) J. Mol. Biol., 181, 411.

6) Okayama, H. and Berg, P. (1982) Mol. Cell Biol., $2,161$.

7) Sternberg, N., Tiemeier, D. and Enquist, L. (1977) Gene, 1, 255.

8) Hohn, B. (1979) Methods in Enzymology, 68, 299.

\section{お 詫ひ}

前号 (Vol. 26 No. 3 通巻 145 号) 本文 42 頁図 5 の中, 以下の部分が欠落していました。おわび申しあげます。

激して左の視蓋部 Coptic 